\title{
Research on Quantitative Demand of Underground Space Development for Urban Rail Transit Station Areas: A Case Study of Metro Line 1 in Xuzhou, China
}

\author{
Liming $\mathrm{Wu}^{1} \cdot$ Haishan $\mathrm{Xia}^{2} \cdot$ Xiaowei $\mathrm{Cao}^{3} \cdot$ Chun $\mathrm{Zhang}^{2} \cdot{\text { Cheng } \mathrm{Dai}^{2}}^{2}$
}

Received: 12 September 2018/Revised: 8 November 2018/ Accepted: 29 November 2018/Published online: 21 December 2018

(C) The Author(s) 2018

\begin{abstract}
Under the background of the rapid development of urban rail transit in China, the development demand of urban underground space has also greatly increased especially in the rail transit station areas. In this paper, taking the high-speed railway station area of Xuzhou Metro Line 1 as an example, the underground space development demand evaluation is conducted by considering the principle of urban underground space stock planning, the local underground space development conditions, as well as the special planning of the local urban constructions. Using the Analytic Hierarchy Process (AHP), a specific weight indicator scale is employed after the rationality of different weight indicator scales being compared. And then the weight indicator of different function types, i.e., commercial, parking, road, etc., are calculated and laterly utilized to forecast the recent development demand of underground space in the station area. Moreover, the steps to forecast the underground space development demand in rail transit station area are proposed, which can provide a reference for the forecasting of underground space development demand in the urban rail transit station areas.
\end{abstract}

Haishan Xia

hshxia@bjtu.edu.cn

1 School of Civil Engineering, Beijing Jiaotong University, Beijing 100044, China

2 School of Architecture and Design, Beijing Jiaotong University, Beijing 100044, China

3 Department of Engineering and Construction, Xuzhou Urban Rail Transit Co. Ltd, Xuzhou 221000, China

Communicated by Yan Song.
Keywords Urban rail transit - Underground space . Development demand · Forecast

\section{Introduction}

From the perspective of the whole city, the underground space is an important part of the whole urban space; in the form of an organic extension of the upper space, the two together constitute an integrated urban spatial entity. From the characteristics of underground space, it has the development of the irreversible, and it is often difficult to transform and adjust, and it will also form a significant impact on the surrounding and subsequent development. Therefore, with respect to the ground space, underground space development needs forward-looking forecasting to make a scientific, rational, orderly, modest development.

\subsection{Urban Underground Space Development Demand}

Urban underground space (UUS) is a valuable non-renewable resource, which needs careful consideration in urban planning. The development of underground space can promote and optimize the planning of land use, realize the diversification of urban functions, guarantee the supply of public utilities, enrich the social life, and contribute to the sustainable development of the city $[1,3]$. Scientific and rational underground space development needs to implement demand forecasting ahead of time and gives priority to UUS's service types and expected functions, as well as the correlation between infrastructure's expected functions and ground space [2]. In order to achieve the sustainable development of urban underground space, it is very important to determine the amount of urban 
underground space development. However, due to the complexity and variability of UUS quantifiable information as the basis for the forecasting of the development volume, the forecast of the UUS development demand is still a challenging task. Li et al. [1,3] took Nanjing Xinjiekou commercial center as an example to determine the UUS's demand and development factors through quantitative and comparative research. Zhao and $\mathrm{Wu}$ [4] took Xicheng District of Beijing as an example to sort out and refine the main factors affecting the development and utilization of underground space in urban central area from two aspects of supply and demand. Moreover, through the establishment of a classification index and quantitative assessment model, the quantitative evaluation of the development potential of underground space development was carried out in the land block as a unit. Xia et al. [5] used a forecasting model to evaluate the potential of 3D space development in Chinese cities to determine and assess the suitability, economic feasibility, and landscape visibility of land use, and assist urban planners in formalizing urban underground space. He et al. [6] used the multiple regression analysis of the Box-Cox transformation to build a forecast model to evaluate the demand of urban underground space, and the research results showed that both population density and per capita GDP have independent forward-forecasting ability for UUS development density. Therefore, it can be seen that the quantitative research on the development demand of urban underground space is more and more important for the stock planning and scientific development of today's cities.

\subsection{Underground Space Development in Urban Rail Transit Station Area}

The planning and development of urban underground space are closely related to the construction of urban rail transit. Generally, urban rail transit stations are chosen to be built in the center and subcentral area of the city, with the function of connecting each city block and forming the urban underground space skeleton. Therefore, as the core of urban public transport, urban rail transit can be used as the basis for the development and utilization of urban underground space. Moreover, the construction of rail transit stations can also bring opportunities for the efficient and economical use of land resources for the development of urban underground space [7]. As early as the beginning of 1990s, Guangzhou began to carry out large-scale urban rail transit construction and paid great attention to the development of underground space in the surrounding areas. In order to make full use of the multi-function of underground space, a systematic development pattern has been formed, which is based on urban rail transit stations, supplemented by underground space development such as underground civil air defense works, underground commerce, underground parking, underground evacuation channels, and utility tunnel [8]. Song et al. [9] combined engineering projects in Beijing, Shanghai, and Shenzhen to analyze the necessity and feasibility of urban rail transit in driving the development of underground space, and pointed out that the scale of underground space development is a key research topic for underground space development in future rail transit station areas. Xiao et al. [10] in their research on the large-scale development and utilization of underground space for urban rail transit specifically pointed out that the structural space constructed by saving engineering investment and intensively using resources replaced traditional earthwork backfilling. As well as the underground space above the subway station platform or on the same floor as the station hall due to the need for deep excavation required by the subway construction method, it is located between the main body of the station and the surrounding buildings, the municipal road or the green space, and the comprehensive underground space with parking, connectivity, or commercial functions belongs to the scale of the underground space in the urban rail transit station area. Guo and Wang [11] analyzed the factors affecting the surrounding space environment factors of Beijing Metro Line 13 and considered that from a range point of view, the urban space around the rail transit station generally refers to the range of the station as the center radius $500-600 \mathrm{~m}$ or adjacent neighborhood. According to their location and functional categories of the city, they are divided into four types: hub space, public center space, residential space, and urban edge space. Nie and Wang [12] discussed the combined mode of rail transit and urban land, used planning, and pointed out that rail stations have great influence on the development of underground space. According to the different influences of the rail transit key stations, general stations and their hinterland and light rail stations on the development demand, the corresponding underground space influences are also different. Among them, the underground space of the key stations has an impact scope of about $500 \mathrm{~m}$, and for the other three types of stations, the scope of influence of underground space diminishes in turn.

However, the development of the area around of the rail transit station is mainly based on the use of rail transport capacity and the 1 -h commuter characteristics, which make the urban land-use development to produce aggregated effects. This usually uses the station as the center of the circle to form a concentric land development model with high- and low-intensity changes. It is connected to the rail stations and overall coordinated development with each other. This model will inevitably drive the development and construction of supporting facilities such as residential areas, commercial and municipal areas around the station. 
With the blowout development of China's urban rail transit construction, the demand for underground space development in the station area is increasing. Combining with the above literature analysis, it can be seen that the research on the underground space development demand forecast in the rail transit station area is indispensable at the quantitative planning level.

\section{Demand Influence Factors and Research Methods}

\subsection{Demand Forecast Influence Factors Analysis}

The investment scale of underground space development is larger than that of the same area space above ground, and the construction period is long and the funds return slowly. Therefore, when the underground space is to be developed, many factors determining the development of forecasting are essential in the early stage.

After investigation and research of the demand forecasting for underground space in many cities, combined with the concrete conditions of rail transit construction, two kinds of factors affecting the demand forecasting of underground space development in rail transit station area are proposed in Table 1.

The demand forecast influence factors have the following characteristics: (1) There are many factors that affect the development demand forecasting of underground space in the rail transit station area, and some factors cannot be quantified. (2) These factors are not independent of each other, the interaction and mutual restraint exist between some factors. (3) The demand forecasting of underground space development is a dynamic process in rail transit station area, and it should be adjusted along with the changes in the social, economic, and policies aspects of the city. (4) While optimizing transport infrastructure, attracting large crowds of people, improving the area's environment, its efficiency also will be improved, but also counterproductive in the development and construction of the ground space.

\subsection{Underground Space Demand Forecasting Method}

Chen et al. [13] through the analogy analysis of the development intensity of the 10 cities first implemented the construction of underground space and used the internal and external variable data contrast and the experience checking method to make a forecast and analysis of the underground space function demand of the Wang Jiadun Business District in the downtown area of Wuhan. As a result, it was found that the total amount of underground space developed can only be used as a reference value for the demand forecast of underground space due to different factors such as location conditions and rail transit modes of various types of land use. Dong [14] pointed out that the demand for underground space should be forecasted and controlled on the basis of various related special plans, such as subway construction demand planning, infrastructure network planning, and underground parking planning. Chen et al. [15] used the method of expert empirical evaluation of the intensity of underground space construction in their forecasting of urban underground space demand. Then, they calculated the underground space demand of each block according to the area and the underground volume ratio of each block, and corrected it with the current development volume of the underground space. Furthermore, the importance of land location division and land-use property classification was emphasized. Gou et al. [16] contrasted and analyzed the existing three methods for forecasting the underground space demand of subindexes, subsystems, and subdivisions in four aspects: systematicity, subjectivity, adaptability, and limitations. It was pointed out that the development and utilization of underground space need to be carried out in stages as the city develops. The forecast results of underground space demand in a certain period of the city should leave room for long-term development. Cao and Feng [17] used the aboveground and underground coordination coefficients of the three functions of parking, civil defense, and commerce to correlate and couple the construction amount of urban land use in order to forecast and calculate the construction amount of urban underground space development. Then, they corrected the forecast results with the related special planning, mainly focusing on the demand forecast of the
Table 1 Affecting factors of the demand forecasting of underground space development

\begin{tabular}{ll}
\hline Driving factors & Construction factors \\
\hline Social development & Project cost \\
Environmental pollution & Construction technology \\
Municipal and transportation infrastructure & Geological conditions \\
Urban disaster prevention and mitigation & Existing environment \\
Some other special facilities & - \\
\hline
\end{tabular}


overall scale of underground space development in the central urban area of the city. Zhao et al. [18] used the reference analogy method (referring to the more mature development scale experience value of other cities in China to forecast the scale of underground space development in urban key areas) and the classification and comprehensive calculation methods (the underground space of the entire city or area is divided into major functional components, and the total amount of underground space demand in a certain period is calculated according to the ratio of functions and per capita demand), and combined with the established index system of hierarchical control elements. The development control idea of underground space in combination with regulatory planning in key urban areas was explored. Zou et al. [19] used the demand forecasting method of underground space land and classification to divide urban land into four categories of residential, public, industrial, and warehousing logistics. According to the survey data of underground space development in certain cities in China, the proportion of ground and underground development of various land types was determined. Then combined with the construction conditions on the ground of the downtown in Danyang city, they forecasted the development demand of underground space and pointed out in the conclusion that the development and utilization plan methods for underground space in small- and medium-sized cities should be guided by the overall development demand of urban space. Gu et al. [20] through comparative analysis of the current three urban underground space prediction methods and their characteristics at home and abroad, including per capita demand, subsystems, and demand intensity, proposed a comprehensive forecasting method that combines the characteristics of multiple forecasting methods based on the actual conditions of the forecasted area. The new method can qualitatively correct the demand for multiple forecasting methods and rationally select a scientific demand value. In their case study, the authors found that the urban space with the subway line as the axis led to the increase in the demand intensity of the land use along the line, and pointed out that the development of urban underground space could seize the opportunity of subway construction.

Above mentioned research showed that the current demand forecast for underground space development contains two levels, i.e., one is the forecast of the total demand for underground space development in the station area, and the other is the demand forecast of various functional types for underground space development in the station area. Moreover, the current forecasting methods are roughly divided into three categories: the first class method includes reference analogy, per capita demand, subindex; the second class method includes dynamic balance, coordination coefficient association coupling, subsystem; the third class method includes empirical checking, construction intensity expert valuation, zoning. Problems and characteristics of the above forecasting methods are shown in Table 2.

The above six methods are basically the forecast of the total amount of macro-development of the urban underground space, and it is difficult to get the demand for the underground space development and construction of the concrete rail transit site. Therefore, we should use special planning as supplementary to control and correct the prediction, and the final prediction results can be used to guide the construction of underground space in specific areas. To this end, this paper puts forward the steps and principles for the forecasting of underground space development demand in rail transit station area: (1) fully combining special planning to forecast, (2) considering location factors, (3) the land function prediction, (4) compliance with the urban development and construction planning of the government institution, (5) the use of subject-objective combination of analytic hierarchy process to calculate index weights, (6) in order to meet the underground space demand of each functional land in different development periods, and the forecast results should conform to the stock planning principles.

\subsection{Analytic Hierarchy Process}

Analytic hierarchy process can be used as a professional method for the analysis and evaluation of overall planning. It has been applied by scholars to analyze and evaluate their related professional issues in many fields, including the demand for urban underground space development. To comprehensively evaluate of the feasibility of underground space demonstration projects, Yin et al. [21] through analysing the indicators of various influencing factors used the improved AHP method to distinguish the weight differences of different indicators, and a scientific rational and operable evaluation method is put forward on the basis of the comprehensive consideration of the various factors. Zhou et al. [22] used the hybrid analytic hierarchy process (AHP) to assess the relationship between tourism competitiveness based on West Virginia resources and neighboring states. Singh and Nachtnebel [23] used the analytic hierarchy process (AHP) developed by Saaty to analyze the implementation of hydropower in Nepal over the past few decades, and to make recommendations for the most suitable scale for Nepal's hydropower development.

However, the research on the AHP itself is mainly focused on the research of the digital scale system and the improvement of traditional methods. Du [24] discussed the scale of $0.1 \sim 0.9$ and pointed out that the scale of $0.1 \sim 0.9$ is a simple and practical judgment criterion which is more in line with the Chinese thinking habit. The clever 
Table 2 Problems and characteristics of forecasting methods

\begin{tabular}{|c|c|c|}
\hline $\begin{array}{l}\text { Characteristics and } \\
\text { Existing Problems }\end{array}$ & Forecasting Methods & Comprehensive Analysis \\
\hline $\begin{array}{l}\text { It is not suitable to be used as a } \\
\text { specific index of development and } \\
\text { control. }\end{array}$ & Reference Analogy & $\begin{array}{c}\text { The per capita demand } \\
\text { method, the construction } \\
\text { intensity expert valuation } \\
\text { method, and the subsystem }\end{array}$ \\
\hline $\begin{array}{l}\text { The population forecast itself is also, } \\
\text { a kind of estimation value, and with } \\
\text { many uncertain factors. }\end{array}$ & Per Capita Demand & $\begin{array}{l}\text { forecast method are all } \\
\text { complementary to the } \\
\text { functional insufficiency of the } \\
\text { above ground space. The }\end{array}$ \\
\hline $\begin{array}{l}\text { It is easy to ignore the connection } \\
\text { between different functions of } \\
\text { underground space. }\end{array}$ & $\begin{array}{l}\text { Subsystem } \\
\text { Forecasting }\end{array}$ & $\begin{array}{l}\text { urban ground space and } \\
\text { underground space have not } \\
\text { yet been studied as a whole. } \\
\text { And it is easy to overlook the }\end{array}$ \\
\hline $\begin{array}{l}\text { It mainly focuses on the demand } \\
\text { forecast of the overall scale of } \\
\text { underground space development in } \\
\text { urban center. }\end{array}$ & $\begin{array}{l}\text { Coordination } \\
\text { Coefficient } \\
\text { Correlation } \\
\text { Coupling }\end{array}$ & $\begin{array}{l}\text { links with the Urban's master } \\
\text { plan; } \\
\text { Reference analogy method, } \\
\text { coordination coefficient }\end{array}$ \\
\hline $\begin{array}{l}\text { The result of demand forecast is } \\
\text { subjective and objective quantitative } \\
\text { forecasting is not enough, which }\end{array}$ & $\begin{array}{l}\text { Construction } \\
\text { Intensity Expert } \\
\text { Valuation }\end{array}$ & $\begin{array}{l}\text { empirical verification method, } \\
\text { etc. are all forecast for the } \\
\text { total demand of underground }\end{array}$ \\
\hline leads to deviation of forecast results. & & $\begin{array}{l}\text { space. The practical guidance } \\
\text { significance in the application }\end{array}$ \\
\hline $\begin{array}{l}\text { The results can only serve as a } \\
\text { reference value for underground } \\
\text { space demand forecasting, and the } \\
\text { guidance of specific development } \\
\text { and construction is not high. }\end{array}$ & hecking & $\begin{array}{l}\text { of specific development } \\
\text { projects is far less than the } \\
\text { land use demand forecast of } \\
\text { each functional type for } \\
\text { underground space. }\end{array}$ \\
\hline
\end{tabular}

mathematical transformation of the judgment matrix based on this scale can solve the consistency problem of AHP. Lu et al. [25] made a comprehensive comparison analysis between the two most commonly used exponential scale and $1 \sim 9$ scale, which proved the incompatibility between the two scales. It is pointed out that the $1 \sim 9$ scale may lead to the error of decision results, and the exponential scale is a conclusion that a good result is reliable. In view of the various digital scales commonly used in AHP, Xiong et al. [26] pointed out the incompatibility between the expert language description and the digital scale and proposed that the selection and evaluation of digital scale should be based on the degree of coincidence with the natural language description. Then based on reasonable linguistic logic assumptions, a general evaluation method was given, so that the decision maker can choose the appropriate digital scale for decision making in practical applications. Against these existing problems of $1 \sim 9$ scale in analytic hierarchy process, the exponential scale and corresponding random consistency test indicators were 
Table 3 Structure of urban construction land

\begin{tabular}{lc}
\hline Land title & Proportion of urban construction land $(\%)$ \\
\hline Residential land & $25.0 \sim 40.0$ \\
Public administration and service land & $5.0 \sim 8.0$ \\
Industrial land & $15.0 \sim 30.0$ \\
Roads and transportation facilities land & $10.0 \sim 25.0$ \\
Green and square land & $10.0 \sim 15.0$ \\
\hline
\end{tabular}

introduced by some scholars according to Weber-Fechner law in psychology and applied it to the evaluation of bridge technology [27]. Dong et al. [28] corrected the misunderstanding of the relationship between 1 and 9 scale and exponential scale, and pointed out the irrationality of the current consistency improvement method. The method of adjusting the consistency of the $1 \sim 9$ scale judgment matrix was extended to the exponential scale judgment matrix, and a new consistency adjustment method based on the sensory judgment matrix was proposed. Yan et al. [29] applied the scale method of 9 degree and 0.618 in AHP to construct judgment matrix. Moreover, the survey data of the national public meteorological service satisfaction in 2010 and 2011 were evaluated. After comparing and analyzing of the main evaluation indicators for 2 years, it is found that when the weight coefficients of all levels were calculated with two different scale methods, the calculation results of the two were relatively close, but the lower the order of the judgment matrix is, the smaller the difference between the two. Moreover, as the order of judgment matrix increases, the difference showed a rising tendency.

AHP is used as an auxiliary method for forecasting urban underground space development demand, although the amount of demand can be calculated quantitatively, but the problem of the rationality of the scope of its own evaluation scale should not be ignored. It is known from the above literature that, in AHP, the 1 9 scaling method proposed by T.L. Saaty is commonly used, but through a lot of domestic and foreign research and the use of effects that can be found, there are some defects in the traditional AHP 1 9 scale, the evaluation results easily lead to appear in reverse order, judgment matrix, thinking out of consistency, and so on problems. Therefore, many researchers have studied the scale and proposed some new scale methods, For example, abroad: $1 \sim 5$ scale, $1 \sim 15$ scale, $x^{2}$ scale, $\sqrt{x}$ scale, etc., domestic: 9/9 9/1 scale, 10/10 18/2 scale, $a^{n}$ scale, $9^{k / 9}$ scale, etc. Therefore, before establishing judgment matrix and calculating weight, we need to consider the problem of selected scale, and it is necessary to carry out the weight difference comparison and analysis of various scales.

\section{The Development Demand Forecasting of Underground Space in Station Area}

This study believes that the principles of demand forecasting should give full consideration to the ground and underground space coordinated development characteristics, in order to make the reasonable configuration and coordination and create a comprehensive sustainable development of urban space.

The station area of underground space development should not only adapt to the requirements of the overall urban development, but also meet its short-term and longterm development rules, in order to realize the reasonable development and the stock of the planning.

According to the sustainable development rules of the short term and long term, the development demand forecasting of the underground space in the rail transit station can be divided into two stages:

1. The overall demand forecasting for each land function type of underground space development in the rail transit station area;

2. The basic demand forecasting for each land function type of underground space development in the rail transit station area.

\subsection{The Overall Demand Forecasting for Each Land Function Type of Underground Space Development in the Rail Transit Station Area}

To make this underground space demand forecasting more scientific and reasonable, based on the "Urban land classification and planning construction land standards" (GB50137-2011) (as shown in Table 3) and other national standards and index and goals (sees in Table 4), according to the actual construction situation, we then determine the forecasting indicators.

Since the actual urban development and construction need to implement in different stages, the demand forecast of underground space development in the rail transit station area is not a one-time construction completion; moreover, along with the development of science technology and renewal of urban construction concept, the development 
Table 4 Forecasting indicators of station area land types

\begin{tabular}{lll}
\hline No. Land title & Explanation \\
\hline (1) & Commercial land & Construction land area per capita $\left(110 \mathrm{~m}^{2}\right.$, National planning level IV standard, represented by $\left.A_{\mathrm{c}}\right)$ \\
(2) & Municipal land & The same as $(1)$ \\
(3) Residential land & Per capita floor area $\left(35 \mathrm{~m}^{2}, 2020\right.$ National Society housing target, represented by $\left.A_{\mathrm{b}}\right)$ \\
(4) Intercity transportation land & Road area per capita $\left(\geq 13 \mathrm{~m}^{2}\right.$, twenty-first-century China City quantitative index, represented by $\left.A_{\mathrm{r}}\right)$ \\
(5) Roads and squares land & The same as (4) \\
(6) Green land & Per capita public green area $\left(11 \mathrm{~m}^{2}\right.$, the urban greening long-term goals in China, represented by $\left.A_{\mathrm{g}}\right)$ \\
(7) Water and other land & The same as $(6)$ \\
(8) Recent demand development & (The value can be determined according to the concrete development plan of the city construction, \\
& ratio & represented by $\left.d_{\mathrm{r}}\right)$ \\
\hline
\end{tabular}

and construction process will also undergo some adjustments in the future. Hence, the demand forecast must take into account the sustainable development of cities; the development and construction of urban underground space also need to give some allowance to the future construction. In this study, the calculated value of development demand for the near term should be part of the total demand for urban sustainable development and construction, and we used $d_{\mathrm{r}}$ to represent the ratio of recent development demand. Therefore, the total development demand for each functional type of underground space in the rail transit station area can be obtained by multiplying the per capita value of urban sustainable development evaluation indicators by the number of planned regional populations, and then adjusting the appropriate development ratio.

\subsubsection{Underground Road Demand Forecast in Station Area}

$S_{\mathrm{ur}}=d_{\mathrm{r}} * h_{\mathrm{r}} * P * A_{\mathrm{r}}$

In the formula: $S_{\text {ur }}$ represents the underground road demand acreage in the forecast station area; $h_{\mathrm{r}}$ represents the ratio of underground road account for the total road acreage in the forecasted station area (the value can be determined by referring to the construction experience of similar cities at home and abroad, as well as the specific conditions of the forecast station area); $P$ represents the total population of future planning year in the forecasted station area (the value can be determined according to the statistical yearbook and regulatory plan, etc.); $A_{\mathrm{r}}$ represents the land-use indicators of the selected per capita road acreage.

\subsubsection{Underground Parking Demand Forecast in Station Area \\ $S_{\mathrm{up}}=d_{\mathrm{r}} * h_{\mathrm{p}} * P *\left(\alpha_{\mathrm{c}} \beta_{\mathrm{c}} A_{\mathrm{c}}+\beta_{\mathrm{b}} A_{\mathrm{b}}\right)+S_{\mathrm{us}}$}

In the formula: $S_{\text {up }}$ represents underground parking demand acreage in the forecast station area; $d_{\mathrm{r}}$ represents the ratio of recent development demand; $h_{\mathrm{p}}$ represents the ratio of underground parking account for the total parking acreage in the forecasted station area (the value can refer to the construction experience of cities at home and abroad; urban central areas are generally between 80 and 90\%, slightly lower in the non-central area and related to the type of building; the ratio of commercial land is higher than that of residential land; in addition, the actual situation in the forecasted station area should be considered, and the larger value is selected as far as possible.); $P$ represents the total population of future planning year in the forecasted station area; $\alpha_{c}$ represents the ratio of commercial land, etc., accounting for the construction land (the value can refer to the relevant regulations of planning construction land structure ratio based on the "Urban land classification and planning construction land standards" (GB50137-2011). Please see Table 3, and it can be determined by combining with the master plan of the forecast station area), $\beta_{\mathrm{c}}$ represents the parking space allocation indicators of commercial land; $\beta_{\mathrm{b}}$ represents the parking space allocation indicators of residential land (these two values can be comprehensively determined by the parking facilities setting standards or criteria of the city in which it is located); $A_{\mathrm{c}}$ represents the selected indicator of per capita construction land acreage, $A_{\mathrm{b}}$ represents the selected indicator of per capita building acreage; $S_{\text {us }}$ represents underground parking demand acreage for primary and secondary schools in the forecasted station area.

\subsubsection{Underground Commercial and Entertainment Demand Forecast in Station Area}

$S_{\mathrm{uc}}=d_{\mathrm{r}} * h_{\mathrm{c}} * a_{\mathrm{c}} * P * A_{\mathrm{c}}$

In the formula: $S_{\mathrm{uc}}$ represents the underground commercial and entertainment demand acreage in forecasted station area; $d_{\mathrm{r}}$ represents the ratio of recent development demand; $h_{\mathrm{c}}$ represents the ratio of underground commercial and entertainment account for the total commercial and entertainment acreage in the forecasted station area (the value 
can be determined by referring to the construction experience of cities at home and abroad, such as Beijing, Shanghai, and Tokyo, as well as the specific situation of the forecasted areas); $a_{\mathrm{c}}$ represents the ratio of commercial and entertainment land in the construction land; $P$ represents the total population of future planning year in the forecasted station area; $A_{\mathrm{c}}$ represents the selected indicator of per capita construction land acreage.

\subsection{The Basic Demand Forecasting for Each Function Type of Underground Space Development in the Rail Transit Station Area}

Before forecasting for the underground space development of each functional type in rail transit station area, we need to consider the following aspects of the case:

1. Overall demand for coordinated development of ground and underground space.

2. Railway station is itself comprehensive development of the project construction.

3. The construction situation of planning and development for the various near-term facilities.

In the actual development and construction process, assuming that the specific station construction scale is known, using AHP method based on the fuzzy mathematics to select the optimal scale and obtaining the relative weight ratio of each function type for underground space development within the rail transit station area, we then can get the basic demand.

Thus in this study, the relationship between the underground space development basic demand of each functional type and the development weight ratio of rail transit station is:

$$
\begin{aligned}
& S_{\mathrm{gb}}: S_{\mathrm{urb}}: S_{\mathrm{upb}}: S_{\mathrm{ucb}}: S_{\mathrm{umb}}=\omega_{1}: \omega_{2}: \omega_{3}: \omega_{4}: \omega_{5} \\
& S_{\mathrm{urb}}=\frac{\omega_{2}}{\omega_{1}} S_{\mathrm{gb}} \quad S_{\mathrm{upb}}=\frac{\omega_{3}}{\omega_{1}} S_{\mathrm{gb}} \quad S_{\mathrm{ucb}}=\frac{\omega_{4}}{\omega_{1}} S_{\mathrm{gb}} \\
& \quad S_{\mathrm{umb}}=\frac{\omega_{5}}{\omega_{1}} S_{\mathrm{gb}} \\
& S \leqq \sum\left(S_{\mathrm{gb}}+S_{\mathrm{urb}}+S_{\mathrm{upb}}+S_{\mathrm{ucb}}+S_{\mathrm{umb}}\right)
\end{aligned}
$$

$S_{\mathrm{gb}}$ is the development amount of the rail transit station itself, $S$ is the total amount of development available in the station area, and $b$ is a shorthand for basic.

\section{Xuzhou Metro Line 1-The underground Space Development Demand Forecasting of High- Speed Railway Station Area}

With its important traffic geographical location, Xuzhou City has made its rail transit construction in the forefront of the country (as shown in Fig. 1). On February 22, 2013, "Xuzhou city rapid rail transit construction planning
(2013 2020)" was formally approved by the National Development and Reform Commission. According to a recent planning and construction program, rail transit Line 1 line construction project was started in early 2015.

In the first phase project of line 1 , the starting point is Hanwang New Town, and the destination is the high-speed railway station: line length of $23.1 \mathrm{~km}, 16$ stations, including 14 underground stations, 2 elevated stations, the average station spacing of $1.497 \mathrm{~km}$ (see Fig. 2).

Among them, the high-speed railway station is the terminus of the one phase of the project, shouldering the responsibility that connects the Xuzhou high-speed rail station and Xuzhou east station of long-distance passenger transportation. The location relationship between it and the east railway station is shown in Fig. 3 .

According to the land development planning and layout in "Xuzhou city high-speed railway station areas regulatory detailed planning" (2010), the region has the Phoenix Mountain and Cuiping Mountain, has two residential communities, has been built green window, golden age and other residential districts, and planned population of about 5.2 million people.

By the end of 2014, in order to accelerate the development of high-speed rail station area, to combine with the recent construction of rail transit line 1 and high-speed railway station, to further strengthen the community service functions of Xuzhou high-speed railway station area, and to provide convenience to visitors, the one-stop service, based on the surrounding neighborhoods which are gradually formed in high-speed railway station, here is three supporting projects to be implemented by Xuzhou city government and Xuzhou railway office: Qiu Hill business Park, high-speed railway station area neighborhood center and high-speed railway station area nine-year coherent education school.

Among them, Xuzhou high-speed railway station area neighborhood center project is located east of the highspeed railway station area Hong Chang Road, south of Daming Lake Road, covers an area of 42.4 acres, total construction area of $51,853 \mathrm{~m}^{2}$, and will be divided into two parts on the ground and underground development and construction. The neighborhood center will also serve as a basic service place for the communities near the high-speed rail station area. Its main functions include the farmers' market, convenience breakfast, affordable pharmacies, medical and health service centers, cultural and sports centers, elderly activity rooms, convenience stores, postal savings, the office room and the white-collar apartments, etc. The architectural renderings of the neighborhood center are shown in Fig. 4. 


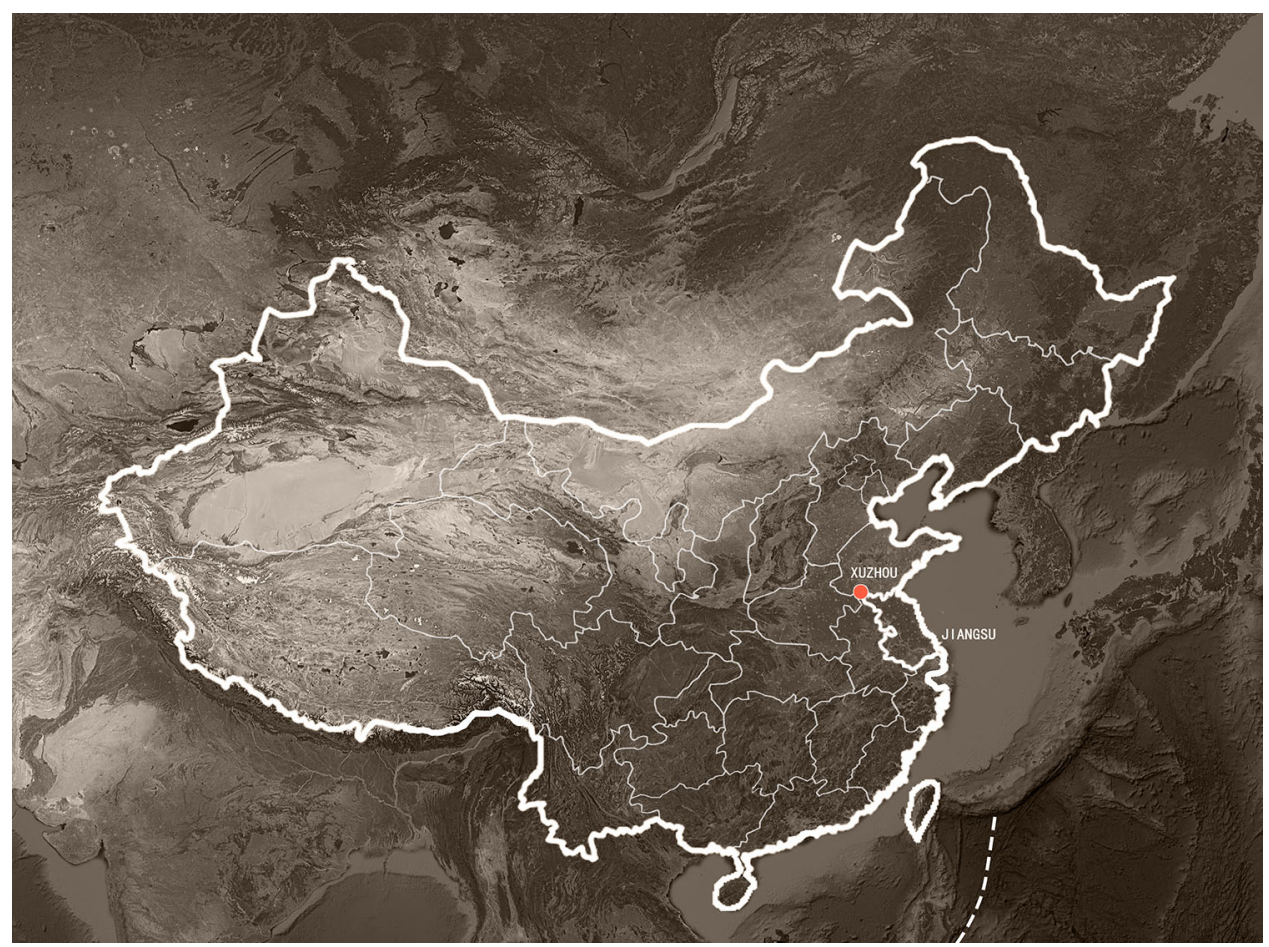

Fig. 1 Xuzhou location

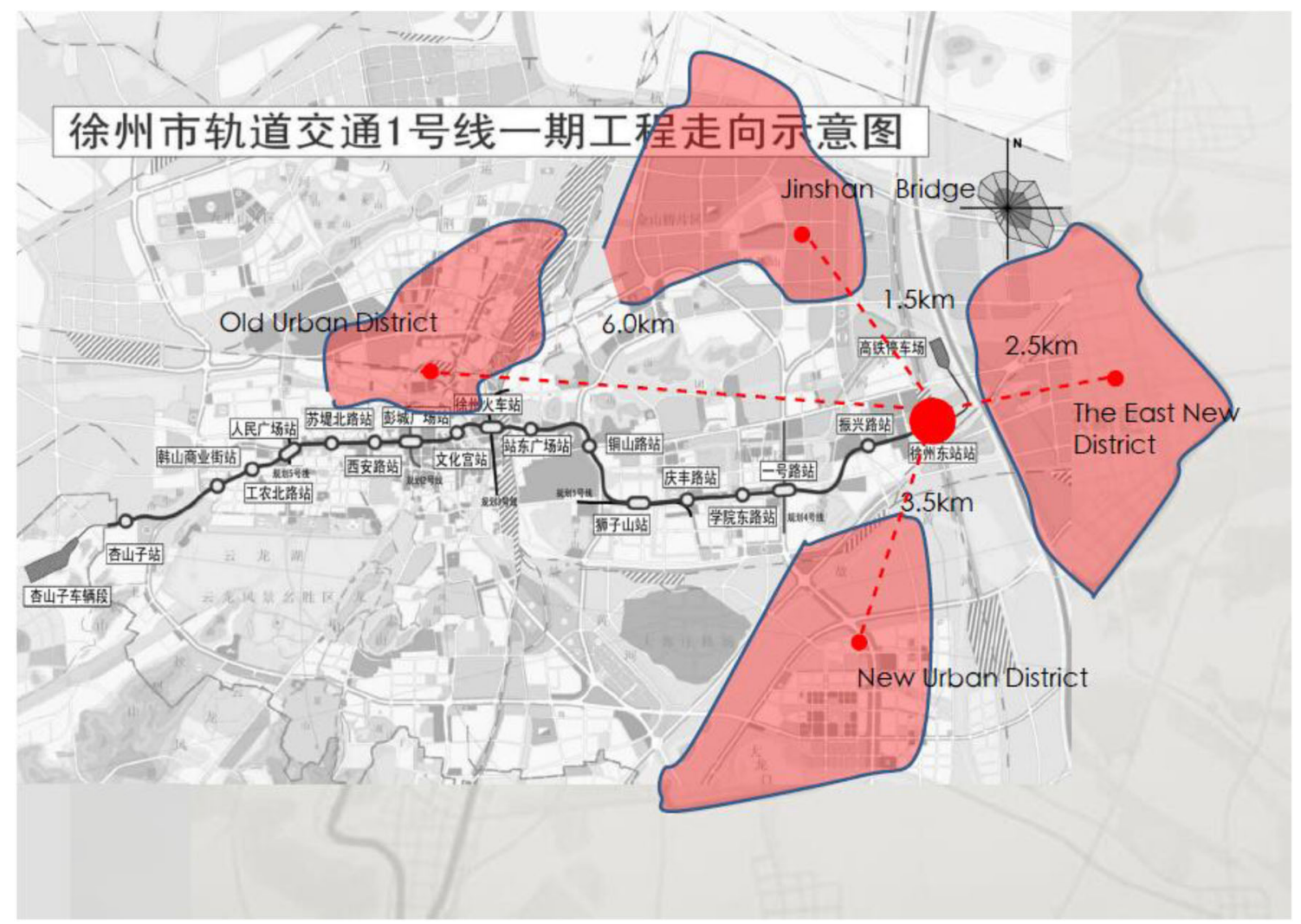

Fig. 2 Metro line 1 and the high-speed railway station 


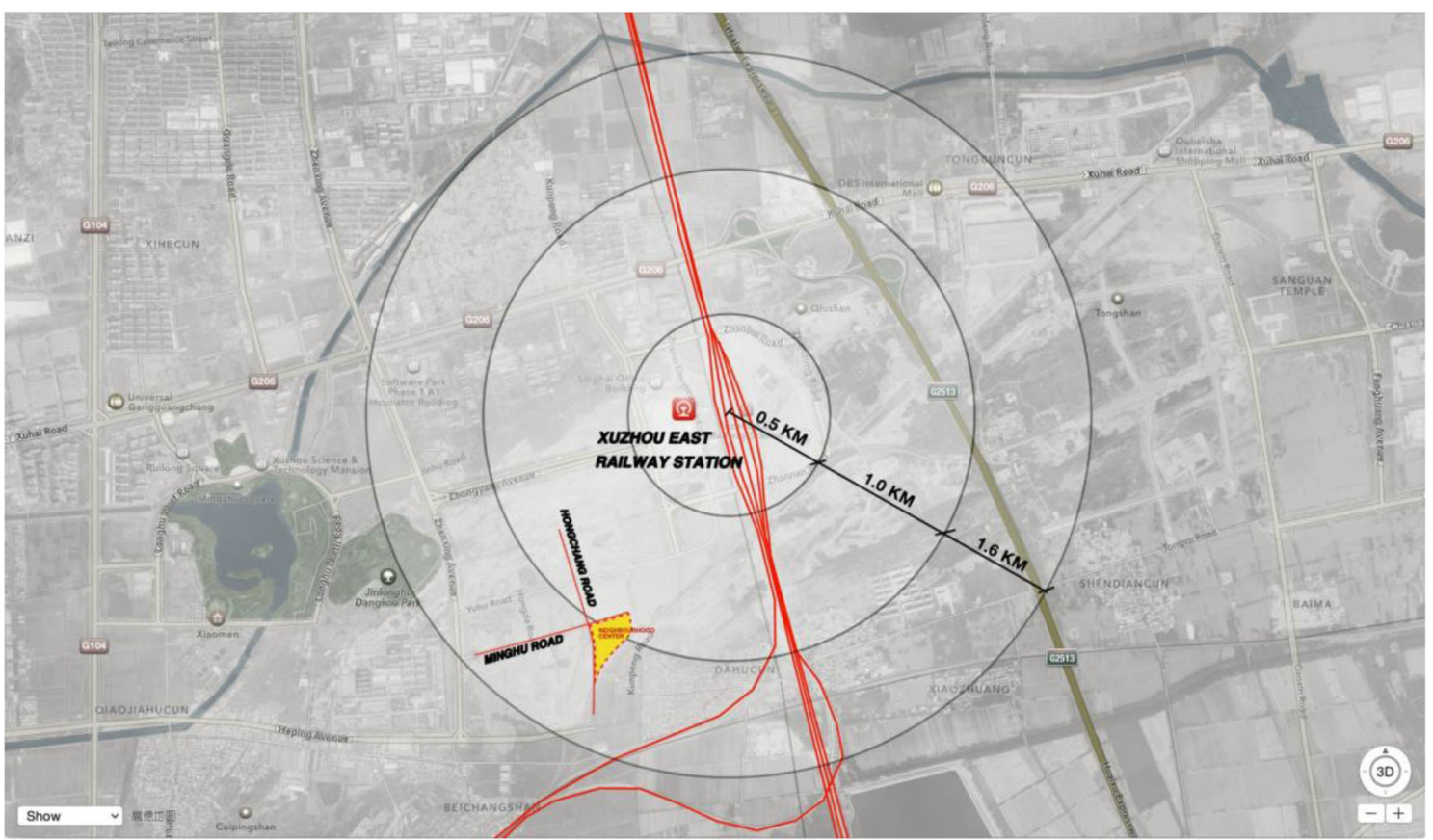

Fig. 3 The neighborhood center location

\subsection{Total Demand Forecast of Each Functional Type Development}

The Metro high-speed railway station is located in the southeast side of the national high-speed railway station square in Xuzhou, and is near by the south side of the national railway station yard. The station is a two-storyisland platform station, and the middle part of the platform is the effective platform area of the $98 \mathrm{~m}$ long (forward reserved $118 \mathrm{~m}$ ) and $12 \mathrm{~m}$ wide (see Fig. 5).

\subsubsection{Underground Road}

$A_{\mathrm{r} 1} \geq 13 \mathrm{~m}^{2}$ (Chinese city of quantitative indicators in the twenty-first century) and $A_{\mathrm{r} 2} \geq 12.0 \mathrm{~m}^{2}$ ("Urban land

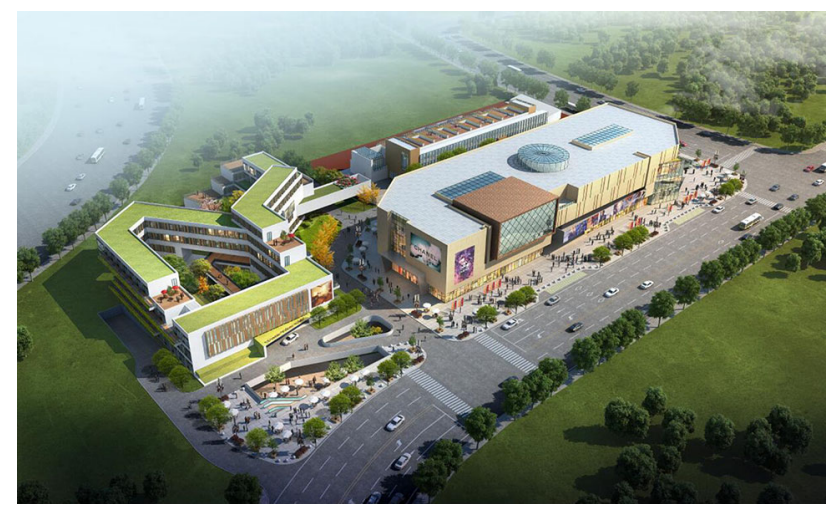

Fig. 4 The neighborhood center of high-speed railway station area classification and planning construction land standards"GB50137-2011) take larger values.

$d_{\mathrm{r}}=0.79$ [according to "Xuzhou city rapid rail transit construction plan (2012-2018)]," the rail Transit Line 1 long-term net plan is $29.1 \mathrm{~km}$, and the recent construction plan in the 1st Line of nets is $23.1 \mathrm{~km}$.

$h_{\mathrm{r}}=0.1$ (the reference value coming from many studies) $S_{\text {ur }}=d_{\mathrm{r}} \times h_{\mathrm{r}} \times P \times A_{\mathrm{r}}=0.79 \times 0.1 \times 5.2 \times$ $10^{4} \times 13=53404 \mathrm{~m}^{2}$

$S_{\mathrm{ur}}$ - the total demand for the development of underground roads

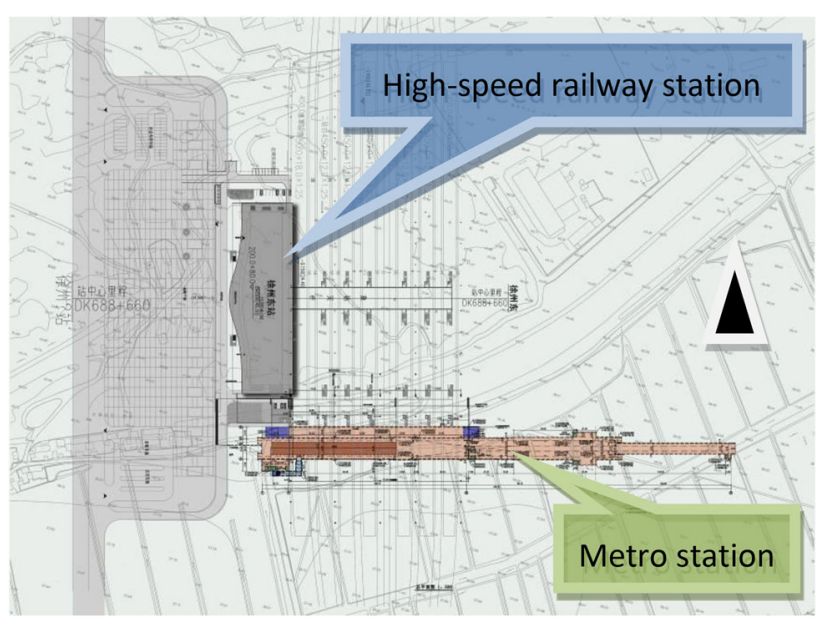

Fig. 5 Schematic diagram of high-speed railway station 
$A_{\mathrm{r}}$ - per capita road area

$d_{\mathrm{r}}$-recent demand development ratio

$h_{\mathrm{r}}$ - underground road area ratio

$P$ - the forecast area total population

\subsubsection{Underground Parking}

$h_{\mathrm{p}} \geq 0.8$ ("Xuzhou City Building Parking facilities set standards and guidelines," Xuzhou II parking area, see Table 5)

$\alpha_{c}=0.3$ ["Xuzhou high-speed railway station peripheral area regulatory detailed planning (2010)," "Urban land classification and planning construction land standards" (GB50137-2011)]

$\beta_{\mathrm{c}}=0.3$ (Xuzhou II parking, commercial building, lookup table)

$\beta_{\mathrm{b}}=0.6$ (Xuzhou II parking, residential building, lookup table)

$S_{\mathrm{us}}$ - (1. school buildings (middle and primary schools, kindergartens): 1.0 parking/100 teachers and students. 2 . "urban area of Xuzhou City, small and medium school layout special planning": 60-70 seat/thousand index, the number of students in the forecast area is 3120 people, and the parking area of the city periphery is controlled by 15-20 square meters/student.)

$S_{\text {up }}=d_{\mathrm{r}} \times h_{\mathrm{p}} \times P \times\left(\alpha_{\mathrm{c}} \beta_{\mathrm{c}} \quad A_{\mathrm{c}}+\beta_{\mathrm{b}} \quad A_{\mathrm{b}}\right)+S_{\text {us }-}$ $=0.79 \times 0.8 \times 5.2 \times 104 \times(0.3 \times 0.3 \times 110+0.6$

$\times 35)+3120 \times 0.01 \times 20=1016121.6 \mathrm{~m}^{2}$

$S_{\text {up }}$ - the total demand for the development of underground parking

$h_{\mathrm{p}}$ - underground parking area ratio

$\alpha_{\mathrm{c}}$-commercial land-use ratio

$\beta_{\mathrm{c}}$ - commercial building parking match index

$\beta_{\mathrm{b}}$-residential building parking match index

$S_{\mathrm{us}}$ - forecast demand area of primary and middle school underground parking

\subsubsection{Underground Commerce and Recreation}

$h_{\mathrm{c}}=0.1$ (according to some various domestic and international literature and research materials)

$a_{\mathrm{c}}=0.17$ ["Xuzhou high-speed railway station peripheral area regulatory detailed planning (2010)"] $S_{\mathrm{uc}}=d_{\mathrm{r}} * h_{\mathrm{c}} * a_{\mathrm{c}} * P * A_{\mathrm{c}}=0.79 * 0.1 * 0.17 * 5.2 * 10^{4} * 110=$ $76819.6 \mathrm{~m}^{2}$

$S_{\mathrm{uc}}$ - the total demand for the development of underground commerce

$h_{\mathrm{c}}$ - underground commerce facilities area ratio

$a_{\mathrm{c}}$-commerce and recreation land-use ratio

\subsection{Basic Demand Forecast of Each Functional Type Development}

\subsubsection{Establish the Development Hierarchy}

According to "Xuzhou City rapid rail transit construction planning (2013-2020)," since 2014 the Xuzhou Government Railway Office is about to develop and construct the supporting facilities projects in high-speed railway station area: first, built three criteria layers: rail transportation, commercial services, and schools; second, refine the above three development functions; and third, subdivide into five specific construction scheme layers: rail transit station, underground road, underground parking, commercial and entertainment facilities, and municipal facilities (see Fig. 7).

\subsubsection{Select Scale}

Here, we have compared and analyzed the differentiation of various scale methods, respectively, to find out the scale method for determining the forecasting demand weight of underground space development in the rail transit station area (see Table 6).

Table 5 Part of Xuzhou City vehicle standard parking match index

\begin{tabular}{|c|c|c|c|}
\hline No. & Building types & Units & $\begin{array}{l}\text { Motor vehicle } \\
\text { index } \\
\text { II district }\end{array}$ \\
\hline 1 & Residence: commercial housing and serviced apartments/no household & $\begin{array}{l}\text { Parking space } / 100 \mathrm{~m}^{2} \text { building } \\
\text { area }\end{array}$ & 0.6 \\
\hline 5 & $\begin{array}{l}\text { Commercial finance: supporting commercial facilities (small supermarket, } \\
\text { convenience store, stores) }\end{array}$ & $\begin{array}{l}\text { Parking space } / 100 \mathrm{~m}^{2} \text { building } \\
\text { area }\end{array}$ & 0.3 \\
\hline 11 & Schools: primary and middle school, kindergartens & $\begin{array}{l}\text { Parking space/100 teacher and } \\
\text { student }\end{array}$ & 1.0 \\
\hline
\end{tabular}

The quote from "Xuzhou City Building Parking facilities set standards and guidelines"

II District: Old Town and Zhai mountain groups (except for I district), Dam mountain groups, Big Guozhuang airport, Development zone, Xuzhou new District, the parking partition diagram as shown in Fig. 6 
Fig. 6 Parking zoning of Xuzhou city
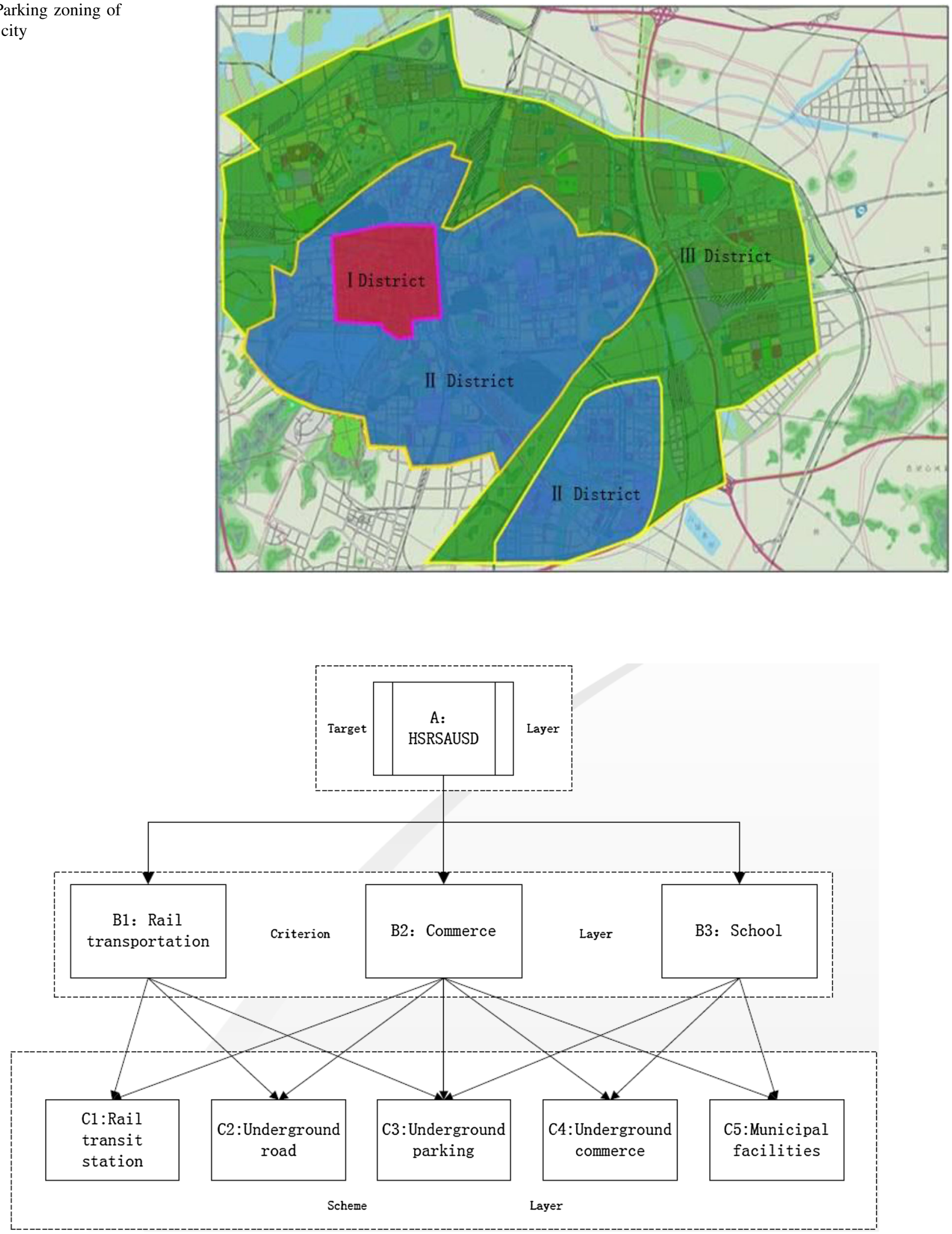

Fig. 7 The underground space development hierarchy of high-speed railway station area 
Table 6 Scale level and the scale type

\begin{tabular}{|c|c|c|c|c|c|c|c|c|c|}
\hline \multirow[t]{2}{*}{ Scale type } & \multicolumn{9}{|c|}{ Scale level } \\
\hline & Equally & Tiny & Slightly & More & Obviously & Very & Strongly & More strongly & Extremely \\
\hline $1 \sim 9$ & 1 & 2 & 3 & 4 & 5 & 6 & 7 & 8 & 9 \\
\hline $1 \sim 5$ & 1 & 1.5 & 2 & 2.5 & 3 & 3.5 & 4 & 4.5 & 5 \\
\hline $9 / 9 \sim 9 / 1$ & 1.000 & 1.125 & 1.286 & 1.500 & 1.800 & 2.250 & 3.000 & 4.500 & 9.000 \\
\hline $10 / 10 \sim 18 / 2$ & 1.000 & 1.222 & 1.500 & 1.857 & 2.333 & 3.000 & 4.000 & 5.667 & 9.000 \\
\hline$\sqrt{x}$ & 1 & $\sqrt{2}$ & $\sqrt{3}$ & $\sqrt{4}$ & $\sqrt{5}$ & $\sqrt{6}$ & $\sqrt{7}$ & $\sqrt{8}$ & $\sqrt{9}$ \\
\hline$a^{0} \sim a^{8}$ & 1.000 & 1.316 & 1.732 & 2.279 & 3.000 & 3.947 & 5.194 & 6.836 & 9.000 \\
\hline $9^{0 / 9} \sim 9^{8 / 9}$ & 1.000 & 1.277 & 1.629 & 2.080 & 2.655 & 3.389 & 4.327 & 5.523 & 7.050 \\
\hline
\end{tabular}

$a^{8}=9(n=8, a=\sqrt[8]{9}=1.316)$

Table $7 \quad$ 1-9 scale

\begin{tabular}{llllll}
\hline Judgment matrix & Single-sorting weight vector & $\lambda_{\max }$ & CI & RI & \multicolumn{2}{c}{ CR } \\
\hline $\mathrm{A}$ & $(0.6348,0.2872,0.0780)^{\mathrm{T}}$ & 3.0940 & $\mathbf{0 . 0 4 7 0}$ & 0.52 & 0.0904 \\
$\mathrm{~B}_{1}$ & $(0.6250,0.2385,0.1365)^{\mathrm{T}}$ & 3.0183 & $\mathbf{0 . 0 0 9 1}$ & 0.52 & 0.0176 \\
$\mathrm{~B}_{2}$ & $(0.4101,0.1638,0.0968,0.2823,0.0470)^{\mathrm{T}}$ & 5.3289 & $\mathbf{0 . 0 8 2 2}$ & 1.12 & 0.0734 \\
$\mathrm{~B}_{3}$ & $(0.1865,0.1265,0.6870)^{\mathrm{T}}$ & 3.0940 & $\mathbf{0 . 0 4 7 0}$ & 0.52 & 0.0904 \\
\hline
\end{tabular}

Table 8 1-5 scale

\begin{tabular}{llllll}
\hline Judgment matrix & Single-sorting weight vector & $\lambda_{\max }$ & CI & RI & CR \\
\hline $\mathrm{A}$ & $(0.5443,0.3257,0.1299)^{\mathrm{T}}$ & 3.0324 & $\mathbf{0 . 0 1 6 2}$ & 0.52 & 0.0311 \\
$\mathrm{~B}_{1}$ & $(0.5242,0.2785,0.1973)^{\mathrm{T}}$ & 3.0037 & $\mathbf{0 . 0 0 1 8}$ & 0.52 & 0.0036 \\
$\mathrm{~B}_{2}$ & $(0.3393,0.1849,0.1304,0.2658,0.0795)^{\mathrm{T}}$ & 5.1213 & $\mathbf{0 . 0 3 0 3}$ & 1.12 & 0.0271 \\
$\mathrm{~B}_{3}$ & $(0.2338,0.1896,0.5766)^{\mathrm{T}}$ & 3.0385 & $\mathbf{0 . 0 1 9 3}$ & 0.52 & 0.0370 \\
\hline
\end{tabular}

\subsubsection{Consistency Check}

$A=\left[a_{i j}\right]_{n \times n}$, that is :

$$
A=\left[\begin{array}{cccc}
a_{11} & a_{12} & \ldots & a_{1 n} \\
a_{21} & a_{22} & \ldots & a_{2 n} \\
\ldots & \ldots & \ldots & \ldots \\
a_{n 1} & a_{n 2} & \ldots & a_{n n}
\end{array}\right] \text { and meet : } \quad a_{i j}=1 \cdot i=j
$$

C.R. (Consistent Matrix R) is a measure of consistency of judgment matrix standard; when C.R. $<0.1$, it is considered that the consistency of the judgment matrix can be accepted, which indicates that the qualitative judgment is logically, and it meets the transfer requirements.

C.I. $=\frac{\lambda_{\max }-n}{n-1}$

C.R. $=\frac{\text { C.I. }}{\text { R.I. }}$

C.I. (Consistent Indicator), R.I. (Matrix R Indicator).

\subsubsection{Calculation Process}

According to the hierarchy structure of the underground space development in the high-speed railway station area, the judgment matrix was established between the different levels, in which the maximum eigenvalue, feature vector, consistency check and weight ranking of different scales are calculated by MATLAB program, as shown in Tables 7, 8, 9, 10, 11, 12 and 13.

From the above seven calculation table, we can see that all four hierarchical ranking of the $\mathrm{CR}$ values were less than 0.1 , so they are in accord with the requirement of consistency, and the consistency of 9/9-9/1 scale is best (C.I. absolute values, the smaller the better).

Therefore, according to the principle of the AHP, the 9/9-9/1 scale is selected to establish the judgment matrix. The weight vector calculated is used as the ratio of the basic demand forecasting of the each functional type for underground space development in the high-speed railway station area of Xuzhou Metro 1 line, namely, 
Table 9 9/9-9/1 scale

\begin{tabular}{|c|c|c|c|c|c|}
\hline Judgment matrix & Single-sorting weight vector & $\lambda_{\max }$ & $\mathrm{CI}$ & RI & $\mathrm{CR}$ \\
\hline A & $(0.4494,0.3528,0.1978)^{\mathrm{T}}$ & 3.0001 & $4.4787 e-05$ & 0.52 & $8.6130 \mathrm{e}-05$ \\
\hline $\mathrm{B}_{1}$ & $(0.4093,0.3145,0.2762)^{\mathrm{T}}$ & 3.0001 & $7.2584 \mathrm{e}-05$ & 0.52 & $1.3958 \mathrm{e}-04$ \\
\hline $\mathrm{B}_{2}$ & $(0.2645,0.1999,0.1696,0.2354,0.1305)^{\mathrm{T}}$ & 5.0155 & 0.0039 & 1.12 & 0.0035 \\
\hline $\mathrm{B}_{3}$ & $(0.2769,0.2721,0.4510)^{\mathrm{T}}$ & 3.0100 & 0.0050 & 0.52 & 0.96 \\
\hline
\end{tabular}

Table 10 10/10-18/2 scale

\begin{tabular}{|c|c|c|c|c|c|}
\hline Judgment matrix & Single-sorting weight vector & $\lambda_{\max }$ & CI & RI & $\mathrm{CR}$ \\
\hline A & $(0.4954,0.3477,0.1569)^{\mathrm{T}}$ & 3.0026 & 0.0013 & 0.52 & 0.0025 \\
\hline $\mathrm{B}_{1}$ & $(0.4536,0.3011,0.2453)^{\mathrm{T}}$ & 3.0000 & $9.4009 \mathrm{e}-06$ & 0.52 & $1.8079 \mathrm{e}-05$ \\
\hline $\mathrm{B}_{2}$ & $(0.2971,0.1953,0.1531,0.2500,0.1045)^{\mathrm{T}}$ & 5.0380 & 0.0095 & 1.12 & 0.0085 \\
\hline $\mathrm{B}_{3}$ & $(0.2521,0.2380,0.5099)^{\mathrm{T}}$ & 3.0205 & 0.0102 & 0.52 & 0.0197 \\
\hline
\end{tabular}

Table $11 \sqrt{x}$ scale

\begin{tabular}{llllll}
\hline Judgment matrix & Single-sorting weight vector & $\lambda_{\max }$ & CI & RI & CR \\
\hline $\mathrm{A}$ & $(0.4943,0.3325,0.1732)^{\mathrm{T}}$ & 3.0234 & $\mathbf{0 . 0 1 1 7}$ & 0.52 & 0.0225 \\
$\mathrm{~B}_{1}$ & $(0.4796,0.2962,0.2241)^{\mathrm{T}}$ & 3.0046 & $\mathbf{0 . 0 0 2 3}$ & 0.52 & 0.0044 \\
$\mathrm{~B}_{2}$ & $(0.3058,0.1917,0.1468,0.2530,0.1027)^{\mathrm{T}}$ & 5.0804 & $\mathbf{0 . 0 2 0 1}$ & 1.12 & 0.0179 \\
$\mathrm{~B}_{3}$ & $(0.2671,0.2201,0.5128)^{\mathrm{T}}$ & 3.0233 & $\mathbf{0 . 0 1 1 7}$ & 0.52 & 0.225 \\
\hline
\end{tabular}

Table $12 a^{0}-a^{8}$ scale

\begin{tabular}{llllll}
\hline Judgment matrix & Single-sorting weight vector & $\lambda_{\max }$ & CI & RI & CR \\
\hline $\mathrm{A}$ & $(0.5365,0.3395,0.1240)^{\mathrm{T}}$ & 3.0084 & $\mathbf{0 . 0 0 4 2}$ & 0.52 & 0.0081 \\
$\mathrm{~B}_{1}$ & $(0.4960,0.2864,0.2176)^{\mathrm{T}}$ & 3.0000 & $\mathbf{1 . 0 4 1 1 e}-\mathbf{0 9}$ & 0.52 & $2.0021 \mathrm{e}-09$ \\
$\mathrm{~B}_{2}$ & $(0.3281,0.1890,0.1376,0.2618,0.0835)^{\mathrm{T}}$ & 5.0699 & $\mathbf{0 . 0 1 7 5}$ & 1.12 & 0.0156 \\
$\mathrm{~B}_{3}$ & $(0.2267,0.2069,0.5664)^{\mathrm{T}}$ & 3.0336 & $\mathbf{0 . 0 1 6 8}$ & 0.52 & 0.0323 \\
\hline
\end{tabular}

$$
\begin{aligned}
& \mathrm{A} \sim \mathrm{B}(0.4494,0.3528,0.1978)^{\mathrm{T}} \\
& \mathrm{B}_{1} \sim \mathrm{C}(0.4093,0.3145,0.2762,0,0)^{\mathrm{T}} \\
& \mathrm{B}_{2} \sim \mathrm{C}(0.2645,0.1999,0.1696,0.2354,0.1305)^{\mathrm{T}} \\
& \mathrm{B}_{3} \sim \mathrm{C}(0.2769,0.2721,0.4510,0,0)^{\mathrm{T}}
\end{aligned}
$$

\subsubsection{Weight Calculation and Basic Demand Forecasting}

The weight of the scheme $C$ relative to the target $A$ is:

$$
\begin{aligned}
w & =\left(B_{1} \sim C, B_{2} \sim C, B_{3} \sim C\right)(A \sim B) \\
& =\left[\begin{array}{ccc}
0.4093 & 0.2645 & 0.2769 \\
0.3145 & 0.1999 & 0.2721 \\
0.2762 & 0.1696 & 0.4510 \\
0 & 0.2354 & 0 \\
0 & 0.1305 & 0
\end{array}\right]\left[\begin{array}{l}
0.4494 \\
0.3528 \\
0.1978
\end{array}\right] \\
& =\left[\begin{array}{c}
0.3320 \\
0.2657 \\
0.2732 \\
0.0830 \\
0.0460
\end{array}\right]
\end{aligned}
$$

The resulting weight ratio of total ranking is:

$$
\begin{gathered}
w_{1}: w_{2}: w_{3}: w_{4}: w_{5}=0.3320: 0.2657: 0.2732: 0.0830 \\
: 0.0460
\end{gathered}
$$

This is the basic forecasting demand ratio of rail transit station, underground road, underground parking, commercial facilities, and municipal facilities for the underground space development construction in high-speed railway station area of the Xuzhou Metro line 1 recent planning.

"Хuzhou city rapid rail transit construction plan (2012 2018)" shows that the high-speed railway station of Xuzhou Metro line 1 is the underground two-story-island platform station, and its basic development quantity $\left(S_{\mathrm{gb}}\right)$ is about $10,972 \mathrm{~m}^{2}$ (central station + both sides of the equipment and management space + both sides of the orbits + entrances + ventilation pavilion), whereby we get: 
Table $139^{\frac{0}{9}}-9^{\frac{8}{9}}$ scale

\begin{tabular}{llllll}
\hline Judgment matrix & Single-sorting weight vector & $\lambda_{\max }$ & CI & RI & CR \\
\hline $\mathrm{A}$ & $(0.5160,0.3436,0.1404)^{\mathrm{T}}$ & 3.0066 & $\mathbf{0 . 0 0 3 3}$ & 0.52 & 0.0064 \\
$\mathrm{~B}_{1}$ & $(0.4774,0.2931,0.2295)^{\mathrm{T}}$ & 3.0000 & $\mathbf{6 . 9 7 0 5 e}-\mathbf{1 0}$ & 0.52 & $1.3405 \mathrm{e}-10$ \\
$\mathrm{~B}_{2}$ & $(0.3136,0.1921,0.1447,0.2567,0.0929)^{\mathrm{T}}$ & 5.0552 & $\mathbf{0 . 0 1 3 8}$ & 1.12 & 0.0123 \\
$\mathrm{~B}_{3}$ & $(0.2394,0.2206,0.5400)^{\mathrm{T}}$ & 3.0266 & $\mathbf{0 . 0 1 3 3}$ & 0.52 & 0.0256 \\
\hline
\end{tabular}

$$
\begin{aligned}
S_{\mathrm{urb}} & =\frac{0.2657}{0.3320} \times 10,972=8781 \mathrm{~m}^{2} \\
S_{\mathrm{ucb}} & =\frac{0.0830}{0.3320} \times 10,972=2743 \mathrm{~m}^{2} \\
S_{\mathrm{upb}} & =\frac{0.2732}{0.3320} \times 10,972=9029 \mathrm{~m}^{2} \\
S_{\mathrm{umb}} & =\frac{0.0460}{0.3320} \times 10,972=1520 \mathrm{~m}^{2}
\end{aligned}
$$

$S_{\mathrm{gb}}$-rail transit station construction development quantity, $S_{\text {urb }}$ - basic development quantity of underground road in rail transit station area, $S_{\text {upb }}$ - basic development quantity of underground parking in rail transit station area, $S_{\text {ucb }}$-basic development quantity of underground commercial in rail transit station area, $S_{\text {umb }}$-basic development quantity of underground municipal facilities in rail transit station

\subsubsection{Analysis}

Comparing the first section of this chapter, the total demand forecast of each functional type for underground space development of the high-speed railway station area in Xuzhou Metro Line 1 can be seen as follows:

1. The recent commercial basic forecasting demand is less than the total commercial development demand of high-speed railway station area $\left(S_{\mathrm{ucb}}<S_{\mathrm{uc}}=2743 \mathrm{~m}^{2}\right.$ $<76819.6 \mathrm{~m}^{2}$ ).

2. The recent underground road basic forecasting demand is less than the total underground road development demand of high-speed railway station area $\left(S_{\mathrm{urb}}<S_{\mathrm{ur}}=8781 \mathrm{~m}^{2}<53,404 \mathrm{~m}^{2}\right)$.

3. The recent underground parking basic forecasting demand is less than the total underground parking development demand of high-speed railway station area $\left(S_{\text {upb }}<S_{\text {up }}=9029 \mathrm{~m}^{2}<1,016,121.6 \mathrm{~m}^{2}\right)$.

Three indicators are more reasonable, which ensure a good development stock of long-term construction planning of the station area. The architectural design renderings of high-speed railway station are shown in Fig. 8.
Fig. 8 High-speed railway station design sketch of Xuzhou Metro line 1

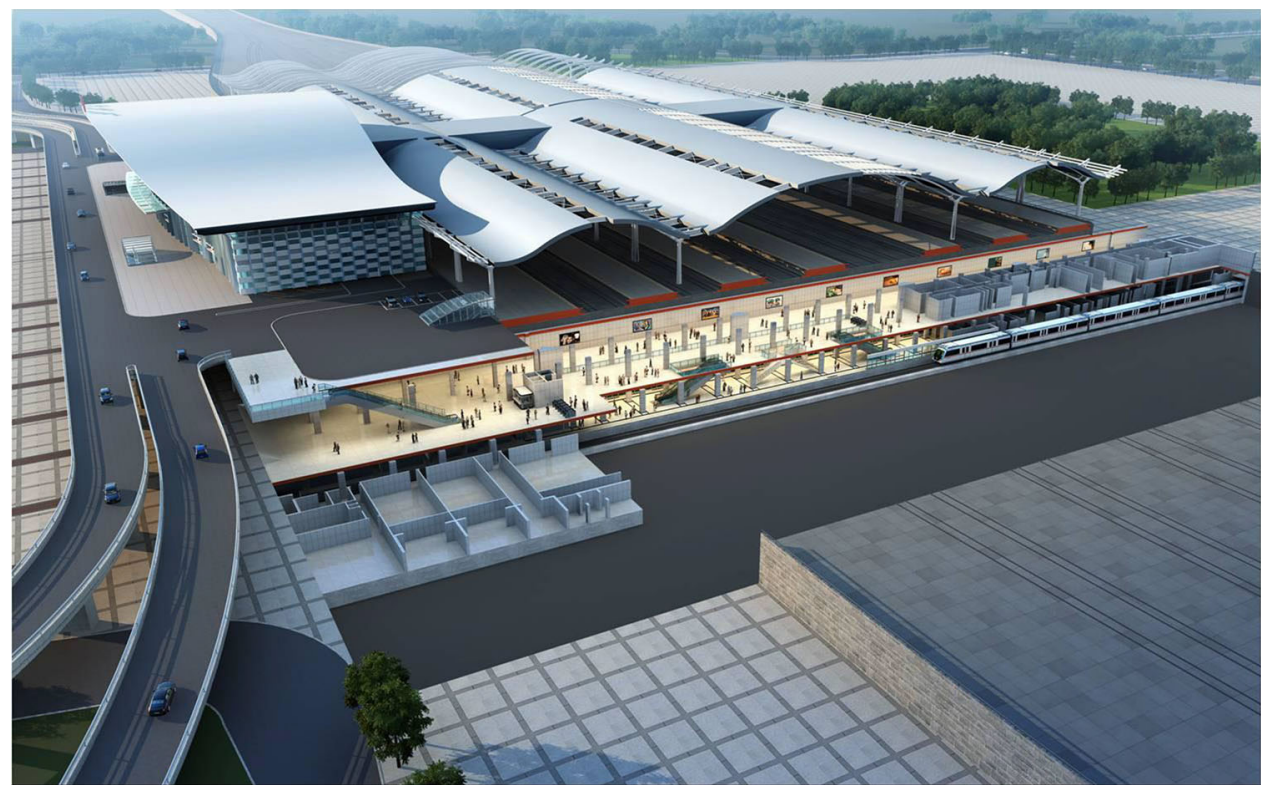




\section{Conclusion}

A proper development demand forecasting can help providing better urban construction as well as city management. In the present investigation, the steps to forecast the underground space development demand in rail transit station area are proposed and applied to a specific case, i.e., the high-speed railway station area of Xuzhou Metro Line 1. This research quantitatively provides a reference for the development forecasting of underground space in urban planning. It should be noted that the demand forecasting of underground space development is a dynamic process, which means there are other aspects that should be considered such as the investment, financing, construction cost, environmental impact, geological conditions, and so on. Therefore, in order to improve the demand forecasting for underground space development in rail transit station area, the follow-up study should consider not only the weights of the forecasting indicators determined using the present proposed subject-objective evaluation, but also the location-specific planning. In further study, with the impact of subjective indicatiors reduced, an optimized weight model is supposed to be established to forecast the development demand of underground space in urban rail transit station areas.

Acknowledgements Funding was provided by National Natural Science Foundation of China (Grant Nos. 51678029, 51778039).

Open Access This article is distributed under the terms of the Creative Commons Attribution 4.0 International License (http://creative commons.org/licenses/by/4.0/), which permits unrestricted use, distribution, and reproduction in any medium, provided you give appropriate credit to the original author(s) and the source, provide a link to the Creative Commons license, and indicate if changes were made.

\section{References}

1. Li H, Li X, Soh CK (2016) An integrated strategy for sustainable development of the urban underground: from strategic, economic and societal aspects. Tunn Undergr Space Technol 55:67-82. https://doi.org/10.1016/j.tust.2015.12.011

2. Bobylev N (2009) Mainstreaming sustainable development into a city's Master plan: a case of urban underground space use. Land Use Policy 26(4):1128-1137. https://doi.org/10.1016/j.land usepol.2009.02.003

3. Li XZ, Xu H, Li C et al (2016) Study on the demand and driving factors of urban underground space use. Tunn Undergr Space Technol 55:52-58. https://doi.org/10.1016/j.tust.2016.02.010

4. Zhao Y, Wu K (2016) Quantitative evaluation of the potential of underground space resources in urban central areas based on multiple factors: a case study of Xicheng district, Beijing. Proc Eng 165:610-621. https://doi.org/10.1016/j.proeng.2016.11.757

5. Xia FZ, Shen Y, Yan J et al (2016) On the potential of urban three-dimensional space development: the case of Liuzhou, China. Habitat Int 51:48-58. https://doi.org/10.1016/j.habitatint. 2015
6. He L, Song Y, Dai S et al (2012) Quantitative research on the capacity of urban underground space-the case of Shanghai, China. Tunn Undergr Space Technol 32:168-179. https://doi.org/ 10.1016/j.tust.2012.06.008

7. Wang XM (2011) Underground space utilization and development of a Nanjing metro transfer station. Urban Rapid Rail Transit 24(1):11-14. https://doi.org/10.3969/j.issn.1672-6073. 2011.01.003 (in Chinese)

8. Chen SZ, Yuan MZ, Lei HM (2011) Practice and experience of the underground space development of Guangzhou rail transit. Urban Rapid Rail Transit 24(1):5-10. https://doi.org/10.3969/j. issn.1672-6073.2011.01.002 (in Chinese)

9. Song MH, Feng AJ, Wang XJ (2005) Promote underground space development through urban rail transit. Urban Rapid Rail Transit 18(1):21-25. https://doi.org/10.3969/j.issn.1672-6073.2005.01. 006 (in Chinese)

10. Xiao HP, Shi PP, Bai YC (2016) Study on the large-scale development of underground spaces of rail transit. Urban Rapid Rail Transit 29(6):16-19. https://doi.org/10.3969/j.issn.16726073.2016.06.004 (in Chinese)

11. Guo C, Wang LJ (2007) Improving the public space environment around the stations on Beijing urban rail way Line 13. Urban Rapid Rail Transit 20(1):68-71. https://doi.org/10.3969/j.issn. 1672-6073.2007.01.020 (in Chinese)

12. Nie HB, Wang M (2015) "Subway + Property" in line with urban land use planning. Urban Rapid Rail Transit 28(2):41-44. https://doi.org/10.3969/j.issn.1672-6073.2015.02.010

(in Chinese)

13. Chen ZL, Zhang P, Wang YB (2006) Discussion on forecast method of underground space demand in urban central area. In China urban planning annual conference proceedings, p 618-621 (in Chinese)

14. Dong PL (2006) The scale prediction of urban underground space development demand. Shanghai Constr Sci Technol 2:35-38. https://doi.org/10.3969/j.issn.1005-6637.2006.02.011 Chinese)

15. Chen ZL, Wang YB, Liu H et al (2007) Prediction of underground space needs. Planners 23(10):9-13. https://doi.org/10. 3969/j.issn.1006-0022.2007.10.002 (in Chinese)

16. Gou CF, Ye F, Zhang JL (2012) Demand forecasting and demand distributional system development method of urban underground space. J Chang' an Univ (Nat Sci Ed) 32(5):58-64. https://doi.org/ 10.3969/j.issn.1006-0022.2007.10.002 (in Chinese)

17. Cao Y, Feng YJ (2013) Exploration on demand model of urban underground space in view of linkage method. Chin J Undergr Space Eng 9(6):1215-1222 (in Chinese)

18. Zhao JW, Wang P, Wang J et al (2015) Underground space development of key districts: Sino-German Eco-park underground space regulatory planning, Qingdao. Planners 8:54-59 (in Chinese)

19. Zou L, Hu YJ, Chen ZF et al (2017) Underground space plan of small and medium-sized city based on demand oriented. Chin J Undergr Space Eng 13(1):7-13 (in Chinese)

20. Gu Q, Li XZ, Sun LP et al (2017) Comparison and analysis of multiple demand forecasting methods for urban underground space. J PLA Univ Sci Technol (Nat Sci Ed). https://doi.org/10. 1016/j.undsp.2016.08.002

21. Yin M, Rui Y, Zhu HH et al (2010) Comprehensive evaluation for underground demonstration project. Chin J Undergr Space Eng 6(2):219-223. https://doi.org/10.3969/j.issn.1673-0836. 2010.02.001

22. Zhou YH, Maumbe K, Deng J et al (2015) Resource-based destination competitiveness evaluation using a hybrid analytic hierarchy process (AHP): the case study of West Virginia. Tour Manag Perspect 15:72-80. https://doi.org/10.1016/j.tmp.2015.03. 007 
23. Singh RP, Nachtnebel HP (2016) Analytical hierarchy process (AHP) application for reinforcement of hydropower strategy in Nepal. Renew Sustain Energy Rev 55:43-58. https://doi.org/10. 1016/j.rser.2015.10.138

24. Du D (2001) Study on 0.1-0.9 scale in AHP. Syst Eng Electr 23(5):36-38. https://doi.org/10.3321/j.issn:1001-506x.2001.05. 012 (in Chinese)

25. Lu YJ, Zhang W, Zeng XL (2003) Exponential scale not being consistent with 1-9 scale. J Eng Math 20(8):77-81 (in Chinese)

26. Xiong L, Liang L, Wang GH (2005) Method research on selection and valuation of numeric scale in analytic hierarchy process. Syst Eng Theory Pract 25(3):72-79. https://doi.org/10.3321/j. issn:1000-6788.2005.03.011 (in Chinese)
27. Sun DS, Zhu Y, Zhou SX (2010) Application of exponential scale of AHP in bridge evaluation. J Chongqing Jiaotong Univ (Nat Sci) 29(6):867-870 (in Chinese)

28. Dong S, Wang YJ, Liu L (2011) Research on methods for improving consistency of judgement matrix based on exponential scale. Comput Technol Autom 30(4):1-4. https://doi.org/10. 3969/j.issn.1003-6199.2011.04.001 (in Chinese)

29. Yan MH, Yao XP, Zhang JF (2014) Determining weight coefficients of meteorological service evaluation criteria with AHP. J Appl Meteorol Sci 25(4):470-475 